\title{
Significance of Elemental Sulphur, Bio-Inoculation and Micronutrient Foliar Applications on Canola Plants Grown in A Newly Reclaimed Soil Calcareous in Nature
}

\section{M.S.A. Ewees and Dalia M. El-Sowfy}

Soils and Water Department, Faculty of Agriculture, El-Fayoum University, El-Fayoum, Egypt.

\begin{abstract}
AIELD experiment was conducted on a slightly saline-alkaline sandy clay loam soil calcareous in nature at a Private Farm of a newly reclaimed area comprising the eastern outskirt desert zone of El-Fayoum district, El-Fayoum Governorate, Egypt during the growing winter season of 2009-2010. The main target of this study was at identifying the positive effects of applied elemental sulphur (ES, i.e., at the rates of $0,150,300$ and $450 \mathrm{~kg} / \mathrm{fed}$, as soil application), seed bio-inoculation (PDB, i.e., P-dissolving bacteria of Bacillus megatherium var. phosphaticum) and some micronutrients (MFS, i.e., $\mathrm{Fe}, \mathrm{Mn}, \mathrm{Zn}$ and $\mathrm{Cu}$ in EDTA-chelated form, as foliar spray) as either solely or combined treatments on canola (Brassica napus L., Serw $4 \mathrm{cv}$.) growth parameters at early flowering stage (i.e., leaf content of chlorophyll a \& $b$, plant height, number of branches plant $^{-1}$, dry matter weight plant ${ }^{-1}$, fruiting zone length and plant nutritional status), yield (number of pods plant ${ }^{-1}, 1000$ seeds weight, seed and straw yields) and seed quality parameters (i.e., seed oil and protein contents). The associated amelioration in some soil properties (i.e., soil $\mathrm{pH}, \mathrm{ECe}$, ESP and available macro and micronutrient contents) were taking into consideration in this study.
\end{abstract}

The obtained results indicated that, the experimental soil could be classified as "Typic Torriorthents, fine loamy, mixed, hyperthermic". Soil suitability class for irrigated agriculture land belongs to a moderately suitable class (S2) in both current and potential conditions as well as moderately and highly suitable classes for cultivating canola plants, respectively. Data showed also a clearly response for ameliorating soil properties, i.e., soil pH, ECe and ESP values as well as soil nutritional status as a result of the applied treatments, particularly those treated with the highest rates of elemental sulphur.

The obtained data emphasized that the achieved amelioration in soil properties was positively reflected on the studied plant parameters at the different growth stages of canola. The best and achieved greatest values were associated with pants subjected to the triple combined treatment (ES x PDB x MFS) as compared to the other combined or solely ones. Further, the applied treatments display an effective role on increasing growth plant characters and nutrient contents of plant tissues at early flowering stage (85 days after sowing), which positively reflected on seed yield and its quality. In 
general, the values of plant parameters were optimized, for bioinoculated and micronutrients foliated plants, with increasing the applied elemental sulphur rates up to 300 or $450 \mathrm{~kg} \mathrm{fed}^{-1}$, with insignificant differences. In this connection, the applied S and Pdissolving bacteria were also resulted in alleviating the antagonism between $\mathrm{P}$ and $\mathrm{Zn}$ in soil solution as well as showed a synergistic relationship represents the most appropriate treatment for obtaining an optimum seed yield with high contents of protein and oil.

So that, it could be recommended that elemental sulphur, seed bioinoculation with P-dissolving bacteria and micronutrients in EDTAchelated forms as foliar spray should be used to alleviate the hazardous effects of either a saline soil or a calcareous in nature, which negatively affect canola seed yield and its quality. In addition, such favourable conditions should be enhance continuous biological activity and nutrients slow release along the growth stages of canola plants, and in turn to minimize their possible losses by either leaching process or volatilization and rationalize use of mineral fertilizers, which represents surplus point for sustainable agriculture system. This approach represents a best strategy in agriculture field that has a longterm positive agronomic value and an effective practice of fertilization management on long-term.

Keywords: Newly reclaimed soil, Canola, Elemental sulphur, Micronutrients foliated plants, Zinc, Plant growth and seed quality parameters.

Canola (Brassica napus L.) presents one of the most important oil crops in the World. Nowadays, it is one of the winter oil crops that grow well in the newly reclaimed soils of Egypt. Canola seeds contain more than $40 \%$ of excellent edible semi-dry oil, hence it is considered a promising oil crop to decrease the gab between oil production and consumption. Also, canola is a specific type of oil seed rape associated with high quality oil and meal. The high nutritional values of oilseed rape meal are resulting from the high energy, protein content and favourable amino acid composition (Omran and Azzam, 2007). Accordingly, looking for high seed yielding of high quality canola variety adapted to the prevailing local Egyptian environment and under a newly reclaimed soil is the main target of the current work.

Egyptian desert soils calcareous in nature are generally characterized by alkaline condition, and then available nutrient contents are surveyed as low levels. So, soil fertilization management practices are ones of the most important agro-management factors that affect the yield and its components of the different crops, especially those grown on the newly reclaimed desert soils (Patel and Shelke, 1998). Balance and effective fertilization management is critical to optimize crop yields and profitability, to ensure crop quality and to sustain soil productivity. The quantity of mineral nutrients required to optimize production depends on the yield potential of the crop, the methods or forms of applied fertilizers and the levels of available nutrients in the soil.

Egypt. J. Soil Sci. 53, No. 2 (2013) 
Canola has a relatively high nutrient requirement and most soils on which the crop is grown are deficient in one or more nutrients for optimum seed yield, oil and protein contents (Grant and Bailey, 1993). Phosphorus is needed during the earliest stage of plant growth. Any $\mathrm{P}$ deficiency during early growth can great reduce yield potential of tops and seeds. Therefore, the amount of $\mathrm{P}$ in canola seeds can be important to help seedling establishment and in determining final seed yields (Bolland, 1997). Deficiencies of P are common and frequently limit canola yield. Therefore, proper P fertilization is important in optimizing canola production. Phosphorus deficiency in canola restricts both top and root growth. With mild deficiencies plant may appear normal but small. With more severe deficiency, the root system is poorly developed and stems are thin and erect with few branches and small, narrow leaves (Bidwell, 1979).

Many solutions were executed to reduce the previously mentioned problems, out of them using bio-inoculation with P-dissolving bacteria and the application of elemental sulphur to the soil. The later is emphasized by the statement of $\mathrm{P}$ availability is a function of either soil $\mathrm{pH}$ or $\mathrm{CaCO}_{3}$ content, and the application of sulphur increased the nutrients availability, particularly $\mathrm{P}$ and micronutrients in the soil. These findings are in harmony by those outlined by Azer et al. (2003) who reported that there was a significant response in seed yield, crude protein and $\mathrm{P}$ contents. Also, in studies by Cheema et al. (2001), found that yield and its components were generally increased with increasing applied phosphorus. Phosphorus fertilization has only a small influence on canola quality. High rates of applied $\mathrm{P}$ increased oil percentage and protein content.

Sulphur is the fourth major nutrient in crop production, however, most crops require as much sulphur as phosphorus. The $\mathrm{N}$ and $\mathrm{S}$ requirements of crops are closely related to optimize the yield of oil crops, because both nutrients are required for protein synthesis. Sulphur is especially critical in canola production and S deficiencies frequently restrict canola yield (Grant and Bialey, 1993). Sulphur is taken up by plant primarily in the $\mathrm{SO}_{4}{ }^{2-}$ form by a specific transport protein. It is a component of the amino acids cysteine and methioniene, essential amino acids for protein synthesis (Bidwell, 1979). Sulphur, while not a constituent of chlorophyll, is needed in the formation of chlorophyll for the photosynthesis process and is also required in crucifera for the synthesis of the volatile oils which accumulate as glucosionlates (Marchner, 1986). The higher protein content of canola as compared with cereals, combined with canola's higher proportion of cysteine and methionine contribute to the larger sulphur requirement (Malhi and Gill, 2002 \& 2006 and Malhi et al., 2007). Production of oil seeds rape aims to produce seeds which are rich in oil and protein contents. The extracted rape seed meal is widely used as feed for farm animals and poultry (Haneklaus et al., 1999).

Adequate soil sulphur in the absence of other limiting factors dramatically increases vegetative growth and total dry matter production. The larger photosynthetically efficient leaf area increases pod numbers and seed yield with

Egypt. J. Soil Sci. 53, No.2 (2013) 
increased amounts of protein in the seeds (Ceccotti, 1996). Application of sulphate-S to canola at seeding time gives the highest increase in yield and $\mathrm{S}$ uptake. Deficiencies of $S$ in canola plants can be prevented and/or corrected and seed yield improved with the use of sulphate-S fertilizer in the growing seasons (Das et al., 2004 and Malhi, 2006). Therefore, adoption of any practice of a nutrient management particularly of zinc which either decreases or increases the applying other nutrient elements like sulphur or translocation and mobility within the plant may influence the nutrition of sulphur, its use efficiency, crop yields and quality. However, it has been reported that zinc plays most important role in increasing yield and improving quality of crops especially oilseeds (Sharma et al., 1990).

The essential roles of micronutrients in plant metabolism, as activators or cofactor in all vital processes of a plant, can not be ignored. This leads undoubtedly to an increase in crop production, which is considered as the main goal in this respect (El-Kabbany et al., 1996). Moussa et al. (1998) reported that the micronutrients enhanced the crop yield because of their beneficial effect on some bio-processes, and in turn on the vegetative of plants. It could be stated that the micronutrient contents may become a limiting factor in crop production in sandy soils, however, Negm and Zahran (2001) reported that supplying micronutrients to plants as foliar spray, at specific physiological growth is undoubtedly of great importance, especially in case of deficient sandy soils. That is true, since the essential roles of micronutrients in plant metabolism, as activators or co-factor in all vital processes of a plant, can not be ignored. Undoubtedly, this leads to increase crop production, which is considered as the main goal in this respect. Also, the statistical analysis confirmed that potential bio-availability of micronutrients in soils was strongly controlled by their chemical forms related to solubility (Abdel Aziz et al., 2002).

The microbial strains such as P-dissolving bacteria are one of the most important agents to sustain P availability in the treated soil. These strain agents are the primary substances controlling the enhanced plant growth, absorption nutrients and photosynthesis process (Mrkovacki and Milic, 2001). Moreover, seed inoculation with bio-fertilizer is economically important as it resulted in reducing the needs of $\mathrm{N}$ and $\mathrm{P}$ fertilizers and improving the crop yield. Azzam and Omran (2005) found that bio-fertilization improved plant growth characters and seed yield of sunflower plants.

The current work aimed to evaluate the integrated effect of applied micronutrients as foliar spray in combination with organic manure and specific effective microorganisms on maize yield and its components.

So, it is of great interest to study the significance of the integrated effect of elemental sulphur as soil application in combination with micronutrients as foliar spray and specific effective microorganisms of bio-inoculation (P-dissolving bacteria) on canola seed yield and its quality. Also, the effect of such treatments

Egypt. J. Soil Sci. 53, No. 2 (2013) 
on ameliorating soil properties represents as an alternative strategy of nutrients availability in the soil calcareous in nature.

\section{Material and Methods}

To achieve the aforementioned target, a filed experiment was conducted on a slightly saline-alkaline sandy clay loam soil calcareous in nature at a Private Farm of a newly reclaimed area comprising the eastern outskirt desert zone of El-Fayoum district, El-Fayoum Governorate, Egypt during the growing winter season of 2009-2010. A representative soil surface sample $(0-30 \mathrm{~cm})$ was taken from the experimental soil site and analyzed to determine the main physicochemical properties and nutrients status according to the standard procedures undertaken by Black el al. (1965) and Jackson (1973) and the obtained results are presented in Table 1.

TABLE 1. Main physico-chemical properties and nutrients status of the experimental soil.

\begin{tabular}{|c|c|c|c|c|c|c|c|}
\hline \multicolumn{3}{|c|}{ Soil characteristics } & Value & \multicolumn{3}{|c|}{ Soil characteristics } & Value \\
\hline \multicolumn{4}{|c|}{ Particle size distribution\%: } & \multicolumn{4}{|c|}{ Soluble cations $\left(m\right.$ molc $\left.L^{-1}\right)$} \\
\hline \multicolumn{3}{|c|}{ Sand } & 51.95 & \multicolumn{3}{|c|}{$\mathrm{Ca}^{2+}$} & 15.80 \\
\hline \multicolumn{3}{|l|}{ Silt } & 26.30 & \multicolumn{3}{|l|}{$\mathrm{Mg}^{2+}$} & 11.90 \\
\hline \multicolumn{3}{|l|}{ Clay } & 21.75 & \multicolumn{3}{|l|}{$\mathrm{Na}^{+}$} & 26.20 \\
\hline \multicolumn{3}{|c|}{ Textural class } & SCL* & \multicolumn{3}{|l|}{$\mathrm{K}^{+}$} & 0.70 \\
\hline \multicolumn{4}{|c|}{ Soil chemical properties: } & \multicolumn{4}{|c|}{ Soluble anions $\left(\mathrm{m} \mathrm{molc}^{-1}\right)$} \\
\hline \multicolumn{3}{|c|}{$\begin{array}{ll}\mathrm{pH} \quad(1: 2.5 & \text { soil water } \\
\text { suspension }) & \end{array}$} & 8.35 & \multicolumn{3}{|c|}{$\mathrm{CO}_{3}^{2-}$} & 0.00 \\
\hline \multicolumn{3}{|c|}{$\mathrm{CaCO}_{3} \%$} & 13.20 & \multicolumn{3}{|l|}{$\mathrm{HCO}_{3}^{-}$} & 2.90 \\
\hline \multirow{2}{*}{\multicolumn{3}{|c|}{$\begin{array}{l}\text { Organic matter \% } \\
\text { Gypsum }\left(\mathrm{CaSO}_{4} \cdot 2 \mathrm{H}_{2} \mathrm{O}\right) \text { content }\end{array}$}} & 1.07 & \multirow{2}{*}{\multicolumn{3}{|c|}{$\begin{array}{l}\mathrm{Cl}^{-} \\
\mathrm{SO}_{4}^{2-}\end{array}$}} & 37.50 \\
\hline & & & 0.95 & & & & 14.20 \\
\hline \multicolumn{3}{|c|}{ ECe (dS/m, soil paste extract) } & 5.42 & \multicolumn{3}{|l|}{ ESP } & 15.75 \\
\hline \multicolumn{8}{|c|}{ Soil available macro- and micro-nutrients $\left(\mathrm{mg} \mathrm{kg}^{-1}\right)$} \\
\hline $\mathrm{N}$ & $\mathrm{P}$ & $\mathrm{K}$ & $\mathrm{S}$ & $\mathrm{Fe}$ & $\mathrm{Mn}$ & $\mathrm{Zn}$ & $\mathrm{Cu}$ \\
\hline 37.15 & 4.07 & 201.35 & 7.94 & 4.23 & 0.80 & 0.65 & 0.38 \\
\hline \multicolumn{8}{|c|}{ Critical levels of nutrients after Lindsay and Norvell (1978) and Page et al. (1982) } \\
\hline Limits & $\mathrm{N}$ & $\mathrm{P}$ & $\mathrm{K}$ & $\mathrm{Fe}$ & $\mathrm{Mn}$ & $\mathrm{Zn}$ & $\mathrm{Cu}$ \\
\hline Low & $<40.0$ & $<5.0$ & $<85.0$ & $<4.0$ & $<2.0$ & $<1.0$ & $<0.5$ \\
\hline Medium & $\begin{array}{l}40.0- \\
80.0 \\
\end{array}$ & $5.0-10.0$ & $\begin{array}{l}85.0- \\
170.0 \\
\end{array}$ & 4.0-6.0 & $2.0-5.0$ & $1.0-2.0$ & $0.5-1.0$ \\
\hline High & $>80.0$ & $>10.0$ & $>170$ & $>6.0$ & $>5.0$ & $>2.0$ & $>1.0$ \\
\hline
\end{tabular}

*SCL $=$ Silt Clay loam

The applied treatments comprised different rates of elemental sulphur, i.e., $0,150,300$ and $450 \mathrm{~kg} \mathrm{fed}^{-1}$, which were thoroughly mixed with topsoil during soil preparation, where the entire quantity of elemental sulphur was incorporated into the soil 21 days before sowing and followed by light irrigation in order to mix it thoroughly with the soil. Canola seeds were inoculated with P-dissolving 
bacteria (PDB) on the same day of sowing, where the used inoculating bacteria consists of an efficient strain of Bacillus megalherium var. phosphate adsorbed on peat-moss power as carrier and registered to Bio-fertilizers Unit, Ministry of Agric. Egypt from which it was obtained. The inoculation was executed by mixing canola seeds with $\left(8 \times 10^{8}\right.$ microbial bacteria cells/pot) at a level of $300 \mathrm{~g}$ $\mathrm{fed}^{-1}$. The applied micronutrients as EDTA-chelated form $(6.0 \% \mathrm{Fe}, 13.0 \% \mathrm{Mn}$, $15.0 \% \mathrm{Zn}$ and $14.0 \% \mathrm{Cu}$ ), which were sprayed on plants at a concentration of $500 \mathrm{mg} / \mathrm{L}$, in a ratio of $3.0 \mathrm{Fe}: 2.0 \mathrm{Mn}: 1.0 \mathrm{Zn}: 0.5 \mathrm{Cu}$, in two equal doses of $400 \mathrm{~L} \mathrm{fsd}^{-1}$ for each one at bloom and early pod formation stages.

The trail was laid out in a split split plot designed with three replicates and the combinations of two rates of micronutrients as foliar spray (MFS) and/or bioinoculation with P-dissolving bacteria (PDB), i.e., 0 and MFS or PDB in main and sub-plot; four elemental sulphur rates, i.e., 0, 150, 300 and $450 \mathrm{~kg} / \mathrm{fed}$ in sub-sub plot; where the number of treatments were $(2 \times 2 \times 4 \times 3)$, i.e., 48 combinations. The experimental unit area was $10.5 \mathrm{~m}^{2}(1 / 400 \mathrm{fed})$ with dimensions of $3.0 \times 3.5 \mathrm{~m}$, each plot included 4 ridges $(3.5 \mathrm{~m}$ length and $30 \mathrm{~cm}$ width).

Phosphorus fertilizer was applied as calcium superphosphate $\left(15.5 \mathrm{P}_{2} \mathrm{O}_{5} \%\right)$ at a rate of $200 \mathrm{~kg} \mathrm{fed}^{-1}$ and thoroughly mixed with topsoil during the final stage of soil preparation. Seeds of canola (Brassica napus L., Serw $4 \mathrm{cv}$.) were sown on $15^{\text {th }}$ December for the growing season of $2009-2010$. All treatments received $\mathrm{N}$ at a rate of $50 \mathrm{~kg} \mathrm{~N} / \mathrm{fed}$ as ammonium nitrate $(33.5 \% \mathrm{~N})$ in two equal doses after thinning and at flowering stage. Potassium was also added as potassium sulphate $\left(48 \% \mathrm{~K}_{2} \mathrm{O}\right.$ ) at a rate of $24 \mathrm{~kg} \mathrm{~K} 2 \mathrm{O} /$ fed applied in two equal splits, i.e., before either planting or flowering.

At mid-maturity stage, i.e., 85 days after planting, the fresh leaves of five plants were harvested at random from each plot to determine chlorophyll a\&b in $\mathrm{mg} \mathrm{g}^{-1}$ fresh weight according to Ranganna (1972). Also, the shoots of five plants were taken at random from each plot for determining some growth parameters, i.e., plant height $(\mathrm{cm})$, number of branches/plant, dry matter weight (g/plant) and fruiting zone length $(\mathrm{cm})$. The plants were transferred immediately from the experimental area to laboratory and dried in an electrical air-draft at $70{ }^{\circ} \mathrm{C}$ for chemical determinations of $\mathrm{N}, \mathrm{P}, \mathrm{K}, \mathrm{Fe}, \mathrm{Mn}, \mathrm{Zn}$ and $\mathrm{Cu}$ according to Chapman and Pratt (1961) and Hesse (1971). Sulphur contents in both soil and plant were determined by using a standard turbidity method (Issam and Sayegh, 2007).

Harvesting was carried out after about 170 days from planting. The plants were dried under sunshine for one week. There after, the pods threshed and seed were cleaned after separation from pods, and then seeds and straw yields were determined as ton/fed. Also, yield components, i.e., number of pods/plant and 1000 seed weight in $g$ were estimated. Seed samples were dried, weighted and analyzed for oil and protein contents. Oil content of seed was determined by solvent extraction method in Soxhlets apparatus with $\mathrm{N}$-hexane as solvent according to A.O.A.C. (1995). Protein content in seeds was calculated through

Egypt. J. Soil Sci. 53, No. 2 (2013) 
multiplying $\mathrm{N}$ content by 6.25 (Kelly and Bliss, 1975). Sulphur was determined using Turbidimetric method according to Tabatabi and Bremner (1970). The obtained data were subjected to the statistical analysis according to the used design. The least significant difference test (LSD) at $\mathrm{p}=0.05$ level was used to verify the differences between treatments as mentioned by Snedecor and Cochran (1980).

\section{Results and Discussion}

\section{A general view on the experimental soil}

The experimental sandy clay loam soil represents some newly reclaimed areas calcareous in nature of the eastern outskirt desert zone of El-Fayoum district that are mainly encompassing the fluvio-lacustrine alluvial plain. It is developed under the prevailing climatic conditions of long hot rainless summer and short mild winter, with scarce amounts of rainfall. Data illustrated in Table 1 indicate that the ECe and ESP values were $5.42 \mathrm{dS} \mathrm{m}^{-1}$ and $15.75 \%$, hence the studied soil was surveyed as a slightly saline-sodic soil. Such results are emphasized by the progressive increments of soluble $\mathrm{Na}^{+}$, which surpassed the soluble $\left(\mathrm{Ca}^{2+}+\mathrm{Mg}^{2+}\right)$ contents that reflected the signs of unfavourable soil aggregation, with a massive structure type, which reflected the signs of imperfect soil aeration.

Also, the analytical data revealed that the studied sandy clay loam soil attains a relatively moderate $\mathrm{CaCO}_{3}$ content $(13.20 \%)$. In addition, the prevailing hot and arid climatic may be ascribed to the low accumulated plant residues (low organic matter content) and soil $\mathrm{pH}$ tended towards the alkaline side (8.35). As for soil fertility status, the studied soil was mostly suffering from macro- and micro-utrients deficient, due to the virgin nature of such desert sandy clay loam soil, and in turn it is poorer in available nutrient contents. According to the critical levels of the studied available nutrients undertaken by Lindsay and Norvell (1978) and Page et al. (1982), the experimental soil is suffering from plant nutrients deficiency, as shown from data illustrated in Table 1. Thus, supplying essential plant nutrients and soil amendments is undoubtedly of great importance for covering the plant needs of nutrients, besides enhancing nutrients availability, mobility and uptake by the grown plants.

\section{Soil taxonomy and evaluation in the current and potential conditions}

\section{a. Soil taxonomy}

According to the obtained results of field work and physio-chemical characteristics as well as based on the outlines of classification system (USDA, 2010), the experimental soil could be classified at a family level of "Typic Torriorthents, fine loamy, mixed, hyperthermic".

\section{b. Soil evaluation for irrigated agriculture land and the tested canola plants}

A parametric system of soil evaluation, under taken by Sys and Verheye (1978), was applied to define the limitations for soil productivity, their intensity degrees and suitability classes for irrigated agriculture land, as shown in Table 2. 
TABLE 2. Soil limitations and rating indices for evaluating the studied soil.

\begin{tabular}{|c|c|c|c|c|c|c|c|c|c|c|}
\hline \multirow[b]{2}{*}{ 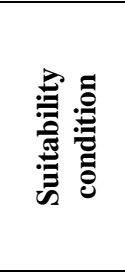 } & \multirow[b]{2}{*}{ 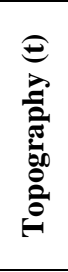 } & \multirow[b]{2}{*}{ 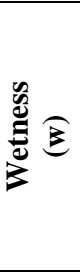 } & \multicolumn{4}{|c|}{$\mathbf{S}$} & \multirow[b]{2}{*}{ 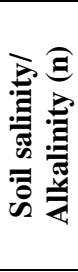 } & \multirow[b]{2}{*}{ 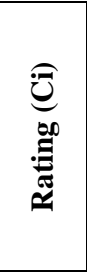 } & \multirow[b]{2}{*}{ 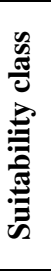 } & \multirow[b]{2}{*}{ 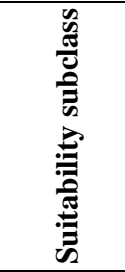 } \\
\hline & & & 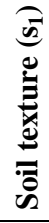 & 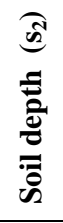 & $\bigcup_{\tilde{J}}^{\infty} \underset{\mathscr{C}}{~}$ & $\sum_{0}^{\Xi}$ & & & & \\
\hline Current & 100 & 100 & 90 & 100 & 90 & 90 & 87 & 63.42 & $\mathrm{~S} 2$ & $\mathrm{~S} 2 \mathrm{~s}_{1} \mathrm{~s}_{3} \mathrm{~s}_{4} \mathrm{n}$ \\
\hline Potential & 100 & 100 & 90 & 100 & 90 & 90 & 100 & 72.90 & $\mathrm{~S} 2$ & $\mathrm{~S} 2 \mathrm{~s}_{1} \mathrm{~s}_{3} \mathrm{~s}_{4}$ \\
\hline
\end{tabular}

The obtained data showed that soil texture $\left(\mathrm{s}_{1}\right), \mathrm{CaCO}_{3}$, gypsum $\left(\mathrm{s}_{4}\right)$ and salinity/alkalinity (n) represent the main limitations for soil productivity, with an intensity degree of slight for all, except of $n$ that exhibits a moderate $(87 \%)$. Also, the suitability classes in the current and potential conditions of the studied soil could be categorized as a moderately suitable (S2) for irrigated agriculture land, with suitability index rating $(\mathrm{Ci})$ ranged 63.42 and $72.90 \%$, respectively.

Also, the evaluation indices of land characteristics are done by rating them and specifying their limitations for certain crops by matching the calculated rating with the crop requirements in different suitability levels as proposed by Sys et al. (1993). In the studied area, without major land improvements, the crop requirements were matched with the present land qualities for processing the current and potential land suitability of the different land units. This approach enables management of different alternatives for specific utilizations that are adapted to the existing limitations to give maximum output. The suitability classes of the experimental soil either in the current or potential condition for the cultivation of canola plants are shown in Table 3.

TABLE 3. Soil suitability for cultivation of canola plants.

\begin{tabular}{|c|c|c|c|c|c|c|c|c|c|c|c|}
\hline \multirow[b]{2}{*}{ ن̃ } & \multirow{2}{*}{ 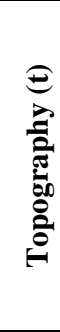 } & \multirow{2}{*}{ 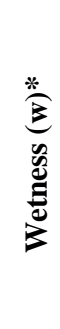 } & \multicolumn{4}{|c|}{$\begin{array}{l}\text { Permanent soil } \\
\text { characteristics }\end{array}$} & \multicolumn{2}{|c|}{$\begin{array}{l}\text { Salinity/ } \\
\text { alkalinity } \\
\text { (n) }\end{array}$} & \multirow[b]{2}{*}{ 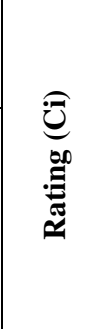 } & \multirow{2}{*}{ 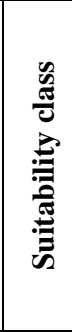 } & \multirow{2}{*}{ 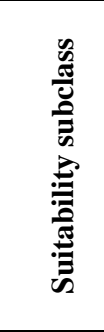 } \\
\hline & & & 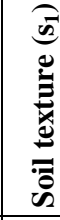 & 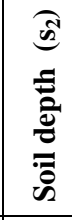 & 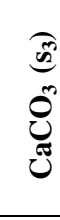 & 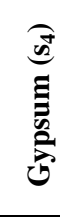 & $\underbrace{0}_{\text {İ }}$ & 产 & & & \\
\hline Current & 100 & 100 & 90 & 100 & 90 & 100 & 90 & 73 & 53.22 & S2 & $\mathrm{S} 2 \mathrm{~s}_{1} \mathrm{~s}_{3} \mathrm{n}$ \\
\hline Potential & 100 & 100 & 90 & 100 & 90 & 100 & 100 & 100 & 81.00 & S1 & $\mathrm{S} 1 \mathrm{~s}_{1} \mathrm{~s}_{3}$ \\
\hline
\end{tabular}

As for this purpose, the land utilization is applicable for the main characteristics of the studied area, which are considered regarding land qualities

Egypt. J. Soil Sci. 53, No. 2 (2013) 
of drainage, salinity and sodicity. Moreover, the resultant adaptations of soil suitability class for cultivating canola plants could be considered as a moderate suitable $\left(\mathrm{S}_{2} \mathrm{~s}_{1} \mathrm{~S}_{3} \mathrm{n}\right)$ and highly suitable $\left(\mathrm{S}_{1} \mathrm{~s}_{1} \mathrm{~s}_{3}\right)$ adaptation in the current and potential conditions, with a rating index of 53.22 and $81.00 \%$, respectively. Also, soil texture $\left(\mathrm{s}_{1}\right), \mathrm{CaCO}_{3}$ content $\%\left(\mathrm{~s}_{3}\right)$, salinity (ECe) and alkalinity (ESP) represent the main limitations for soil productivity in the current condition, with an intensity degree of moderate $(73 \%)$ for ESP and slight $(90 \%)$ for the other three ones. As for the potential condition soil salinity and alkalinity should be corrected, but both soil texture $\left(\mathrm{s}_{1}\right)$ and $\mathrm{CaCO}_{3}\left(\mathrm{~s}_{3}\right)$ will be remained as permanent soil limitations, and then the resultant adaptations of soil suitability class for cultivating canola plants could be considered as a highly suitable $\left(\mathrm{S}_{1} \mathrm{~s}_{1} \mathrm{~s}_{3}\right)$, with a rating index of $81.00 \%$.

Response of some soil properties and available nutrient contents to the applied treatments

a. Some soil properties

Irrespective of elemental sulphur, data in Table 4 showed a clearly response of some soil properties, i.e., pH, ECe and ESP to the applied treatments, particularly those treated with the highest rates of elemental sulphur of 300 or $450 \mathrm{~kg} / \mathrm{fed}$, with insignificant differences. That was true, since elemental sulphur can be oxidized by many soil micro-organisms and forming sulphuric acid, besides the acidity reacts of the microbial activity of Bacillus megatherium var. phosphaticum itself, consequently such acidity media led to lowering soil $\mathrm{pH}$ value. Also, the created sulphuric acid reacts with the native soil $\mathrm{CaCO}_{3}$ and resulting in $\mathrm{CaSO}_{4}$. The latter can be ionized to $\mathrm{Ca}^{2+}$ and $\mathrm{SO}_{4}{ }^{2-}$, which was also reduced soil $\mathrm{pH}$. These results are in agreement with those obtained by Awadalla et al. (2003).

On the other hand, the released soluble ions of $\mathrm{Ca}^{2+}$ can be improved soil aggregation, due to a $\mathrm{Ca}^{2+}$ partial substitution by exchangeable $\mathrm{Na}^{+}$that enhancing the coagulation of Na-separated clay particles and leading to reduce ESP value which encouraging the formation of small clay domains. Such clay domains are coated with soil humified organic substances, and then forming coarse sizes of water stable aggregates isolated or separated by conductive coarse pores that are increased soil permeability and accelerating leaching of a pronounced content of excess soluble salts, and then reducing the ECe value. The effective role of microbial activity in combination with applied elemental sulphur for ameliorating soil properties could be interpreted according to many opinions outlined by El-Fayoumy and Ramadan (2002), Shaban and Omar (2006) and Ashmaye et al. (2008) who reported that many strains produce several phytohormones (i.e., indole acetic acid and cytokinins) and organic acids. Such products simultaneously improving soil structure, i.e., increasing aggregate stability and drainable pores. Consequently, these created conductive pores enhancing the leaching process of soluble salts through irrigation fractions. 
TABLE 4. Effect of elemental sulphur, bio-inoculation and micronutrients foliar spray applied treatments on ameliorating some soil properties.

\begin{tabular}{|c|c|c|c|c|c|}
\hline \multirow{2}{*}{$\begin{array}{c}\text { MFS } \\
\text { (M) }\end{array}$} & \multirow{2}{*}{$\begin{array}{l}\text { PDB } \\
\text { (I) }\end{array}$} & \multirow{2}{*}{$\begin{array}{c}\text { SES } \\
\left(\mathrm{S}, \mathrm{kg} \mathrm{fed}^{-1}\right)\end{array}$} & \multicolumn{3}{|c|}{ Soil properties } \\
\hline & & & pH & $\operatorname{ECe}\left(d S m^{-1}\right)$ & ESP \\
\hline \multirow{8}{*}{ 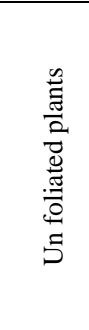 } & \multirow{4}{*}{$\begin{array}{c}\text { Un- } \\
\text { inoculation }\end{array}$} & 0 & 8.32 & 5.37 & 15.75 \\
\hline & & 150 & 7.94 & 5.09 & 14.08 \\
\hline & & 300 & 7.43 & 4.60 & 11.07 \\
\hline & & 450 & 7.40 & 4.55 & 10.82 \\
\hline & \multirow{4}{*}{ Inoculation } & 0 & 8.28 & 5.25 & 15.02 \\
\hline & & 150 & 7.87 & 4.65 & 11.74 \\
\hline & & 300 & 7.34 & 3.63 & 9.30 \\
\hline & & 450 & 7.30 & 3.47 & 8.93 \\
\hline \multirow{8}{*}{ 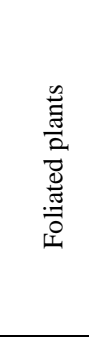 } & \multirow{4}{*}{$\begin{array}{l}\text { Un- } \\
\text { inoculation }\end{array}$} & 0 & 8.30 & 5.30 & 15.30 \\
\hline & & 150 & 7.90 & 4.89 & 13.27 \\
\hline & & 300 & 7.40 & 4.17 & 10.05 \\
\hline & & 450 & 7.35 & 4.05 & 9.79 \\
\hline & \multirow{4}{*}{ Inoculation } & 0 & 8.15 & 5.17 & 14.95 \\
\hline & & 150 & 7.80 & 4.40 & 10.94 \\
\hline & & 300 & 7.27 & 3.20 & 8.10 \\
\hline & & 450 & 7.24 & 3.12 & 7.95 \\
\hline \multirow{7}{*}{\multicolumn{2}{|c|}{$\begin{array}{l}\text { Statistical analysis } \\
\text { (L.S.D. at } 0.05 \text { ) }\end{array}$}} & M & 0.07 & 0.30 & 0.90 \\
\hline & & $\mathrm{I}$ & 0.05 & 0.20 & 1.10 \\
\hline & & $S$ & 0.03 & 0.10 & 1.13 \\
\hline & & M x I & 0.06 & 0.21 & 0.87 \\
\hline & & $M \times S$ & 0.05 & 0.17 & 1.21 \\
\hline & & I x S & 0.04 & 0.13 & 0.91 \\
\hline & & $M \times I \times S$ & 0.06 & 0.21 & 1.25 \\
\hline
\end{tabular}

PDB=P-dissolving bacteria, MFS=Micronutrients foliar spray, SES=Soil elemental sulphur.

\section{b. Soil available nutrients}

In general, the obtained data presented in Table 5 showed that the beneficial effect of the applied treatments, particularly elemental sulphur at a rate of 300 or $450 \mathrm{~kg} / \mathrm{fed}$, with insignificant differences. That was commonly achieved by lowering soil $\mathrm{pH}$, and in turn encouraging the availability of plant essential nutrients, especially phosphorus and $\mathrm{S}$ as macronutrients as well as $\mathrm{Fe}, \mathrm{Mn}, \mathrm{Zn}$ and $\mathrm{Cu}$ as micronutrients.

The superiority of combined effects of added elemental sulphur as soil application and bio-fertilizer as P-dissolving bacteria for the noticeable increment in soil available nutrient contents could be attributed to the pronounced decreases in the values of soil $\mathrm{pH}$, ECe and ESP vs the favourable amelioration in soil biological conditions that encouraging the released nutrients from soil native sources in the available forms as well as easily mobility towards plant roots, and in turn their uptake by plants. In addition, the application of elemental sulphur tends to accelerate the released active inorganic acid $\left(\mathrm{H}_{2} \mathrm{SO}_{4}\right)$

Egypt. J. Soil Sci. 53, No. 2 (2013) 
that leads to controlling soil availability and mobility of nutrients, which are more sensitive to the restriction or the adverseable effects of alkaline soil media. Consequently, the applied elemental sulphur to the soil plays an important role for its nutritional status, whether be under demand as strategic storehouse for unavailable native nutrients. In this connection, Mohammed (2004) interpreted the integrated role of applied elemental sulphur plus bio-fertilizer, which resulted in more pronounced nutrients availability in the soil, on the basis of lowering soil $\mathrm{pH}$ and microbial activity that enhancing the solubilization of nutrient from the native and added sources. Moreover, such prevailing conditions enhancing the slow release of nutrients during the mineralization processes as well as minimizing their possible lose by leaching. These findings are also in agreement with Kaplan et al. (2005) who reported that a potential strategy to enhance nutrients availability is the lowering soil $\mathrm{pH}$ that can be achieved through application of acid-producing fertilizers like sulphur-containing material.

TABLE 5. Effect of elemental sulphur, bio-inoculation and micronutrients foliar spray applied treatments on soil availability of some nutrient contents.

\begin{tabular}{|c|c|c|c|c|c|c|c|c|c|c|}
\hline \multirow{3}{*}{$\begin{array}{c}\text { MFS } \\
(\mathbf{M})\end{array}$} & \multirow{3}{*}{$\begin{array}{c}\text { PDB } \\
\text { (I) }\end{array}$} & \multirow{3}{*}{$\begin{array}{c}\text { Elemental } \\
\text { sulphur, } \\
\mathbf{S} \\
\left(\mathrm{kg} \mathrm{fed}^{-1}\right)\end{array}$} & \multicolumn{8}{|c|}{ Soil available nutrient contents $\left(\mathrm{mg} \mathrm{kg}^{-1}\right.$ soil) } \\
\hline & & & \multicolumn{4}{|c|}{ Macronutrients } & \multicolumn{4}{|c|}{ Micronutrients } \\
\hline & & & $\mathbf{N}$ & $\mathbf{P}$ & $\mathbf{K}$ & $\mathbf{S}$ & $\mathbf{F e}$ & Mn & $\mathbf{Z n}$ & $\mathrm{Cu}$ \\
\hline \multirow{8}{*}{ 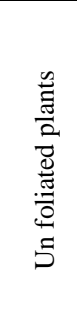 } & \multirow{4}{*}{$\begin{array}{c}\text { Un- } \\
\text { inoculation }\end{array}$} & 0 & 37.45 & 4.10 & 203.70 & 7.95 & 4.25 & 0.84 & 0.68 & 0.40 \\
\hline & & 150 & 43.80 & 4.64 & 214.00 & 9.80 & 4.82 & 1.20 & 0.95 & 0.65 \\
\hline & & 300 & 47.95 & 4.98 & 219.64 & 12.05 & 5.10 & 1.47 & 1.09 & 0.74 \\
\hline & & 450 & 49.06 & 5.25 & 221.87 & 12.20 & 5.27 & 1.52 & 1.15 & 0.78 \\
\hline & \multirow{4}{*}{ Inoculation } & 0 & 39.45 & 6.50 & 212.04 & 9.24 & 5.07 & 0.96 & 0.87 & 0.69 \\
\hline & & 150 & 58.50 & 7.25 & 235.90 & 10.56 & 6.54 & 1.20 & 1.30 & 1.10 \\
\hline & & 300 & 67.38 & 8.05 & 249.56 & 13.98 & 7.32 & 2.35 & 1.65 & 1.40 \\
\hline & & 450 & 68.75 & 8.67 & 254.30 & 14.15 & 7.45 & 2.47 & 1.78 & 1.49 \\
\hline \multirow{8}{*}{ 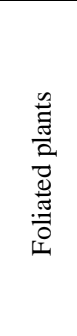 } & \multirow{4}{*}{$\begin{array}{c}\text { Un- } \\
\text { inoculation }\end{array}$} & 0 & 38.50 & 4.95 & 209.40 & 8.15 & 4.70 & 0.90 & 0.74 & 0.53 \\
\hline & & 150 & 49.86 & 5.40 & 224.85 & 11.09 & 5.75 & 1.35 & 1.18 & 0.87 \\
\hline & & 300 & 55.97 & 6.27 & 234.90 & 13.70 & 6.03 & 1.89 & 1.39 & 1.05 \\
\hline & & 450 & 57.10 & 6.40 & 237.05 & 13.92 & 6.15 & 1.95 & 1.45 & 1.10 \\
\hline & \multirow{4}{*}{ Inoculation } & 0 & 40.20 & 7.82 & 218.60 & 8.30 & 4.45 & 0.93 & 0.75 & 0.50 \\
\hline & & 150 & 65.00 & 8.75 & 255.60 & 11.84 & 6.50 & 2.05 & 1.50 & 1.24 \\
\hline & & 300 & 76.97 & 9.40 & 273.25 & 14.55 & 7.98 & 2.69 & 1.94 & 1.74 \\
\hline & & 450 & 78.15 & 9.75 & 276.50 & 14.90 & 8.56 & 2.87 & 2.05 & 1.87 \\
\hline \multirow{7}{*}{ 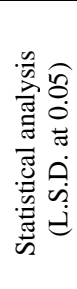 } & \multicolumn{2}{|c|}{ M } & 2.22 & 0.47 & 4.12 & 0.72 & 0.11 & 0.10 & 0.03 & 0.07 \\
\hline & \multicolumn{2}{|c|}{1} & 3.51 & 0.85 & 5.21 & 0.91 & 0.21 & 0.07 & 0.05 & 0.02 \\
\hline & \multicolumn{2}{|c|}{$\mathrm{S}$} & 1.50 & 1.35 & 3.20 & 1.01 & 0.13 & 0.12 & 0.10 & 0.05 \\
\hline & \multicolumn{2}{|c|}{$M \times I$} & 1.70 & 0.61 & 4.71 & 0.82 & 0.11 & 0.09 & 0.07 & 0.10 \\
\hline & \multicolumn{2}{|c|}{$M \times S$} & 1.92 & 0.40 & 3.11 & 0.33 & 0.15 & 0.9 & 0.05 & 0.03 \\
\hline & \multicolumn{2}{|c|}{$\mathrm{I} \times \mathrm{S}$} & 2.11 & 0.42 & 2.27 & 0.51 & 0.17 & 0.7 & 0.09 & 0.10 \\
\hline & \multicolumn{2}{|c|}{$M \times I \times S$} & 1.73 & 0.50 & 2.70 & 0.24 & 0.13 & 0.10 & 0.07 & 0.03 \\
\hline
\end{tabular}

$\mathrm{PDB}=\mathrm{P}$-dissolving bacteria, MFS=Micronutrients foliar spray, $\mathrm{SES}=$ Soil elemental sulphur. 
Plant parameters as affected by the associated ameliorating soil properties

a. Nutrient contents in plant tissues as affected by the applied treatments

The obtained data of the studied macro- $(\mathrm{N}, \mathrm{P}, \mathrm{K}$ and $\mathrm{S})$ and micro-nutrient $(\mathrm{Fe}, \mathrm{Mn}, \mathrm{Zn}$ and $\mathrm{Cu}$ ) contents in the plant tissues of canola at mid-maturity stage of 85 days after planting are presented in Table 6 .

TABLE 6. Effect of elemental sulphur, bio-inoculation and micronutrients foliar spray applied treatments on the studied nutrient contents in plant tissues of canola at mid-maturity stage of 85 days after planting.

\begin{tabular}{|c|c|c|c|c|c|c|c|c|c|c|}
\hline \multirow{3}{*}{$\begin{array}{c}\text { MFS } \\
(\mathbf{M})\end{array}$} & \multirow{3}{*}{$\begin{array}{c}\text { PDB } \\
\text { (I) }\end{array}$} & \multirow{3}{*}{$\begin{array}{c}\text { Elemental } \\
\text { sulphur, } \\
\text { M } \\
\left(\mathrm{kg} \mathrm{fed}^{-1}\right)\end{array}$} & \multicolumn{8}{|c|}{ Nutrient contents in plant tissues of canola } \\
\hline & & & \multicolumn{4}{|c|}{ Macronutrients \% } & \multicolumn{4}{|c|}{ Micronutrients (mg kg ${ }^{-1}$ ) } \\
\hline & & & $\mathbf{N}$ & $\mathbf{P}$ & $\mathbf{K}$ & $\mathbf{S}$ & $\mathbf{F e}$ & Mn & Zn & $\mathrm{Cu}$ \\
\hline \multirow{8}{*}{ 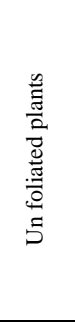 } & \multirow{4}{*}{$\begin{array}{c}\text { Un- } \\
\text { inoculation }\end{array}$} & 0 & 3.15 & 0.42 & 2.70 & 0.16 & 145.4 & 89.5 & 46.2 & 17.3 \\
\hline & & 150 & 3.46 & 0.48 & 2.93 & 0.23 & 159.6 & 95.3 & 54.2 & 19.5 \\
\hline & & 300 & 3.71 & 0.52 & 3.10 & 0.28 & 168.3 & 99.6 & 59.6 & 22.1 \\
\hline & & 450 & 3.80 & 0.55 & 3.20 & 0.32 & 172.7 & 102.8 & 62.9 & 24.3 \\
\hline & \multirow{4}{*}{ Inoculation } & 0 & 3.59 & 0.60 & 2.90 & 0.24 & 165.8 & 95.7 & 54.4 & 20.7 \\
\hline & & 150 & 3.83 & 0.63 & 3.25 & 0.35 & 180.4 & 101.9 & 60.2 & 24.8 \\
\hline & & 300 & 4.00 & 0.67 & 3.49 & 0.40 & 187.2 & 106.5 & 64.6 & 27.9 \\
\hline & & 450 & 4.17 & 0.70 & 3.60 & 0.45 & 193.7 & 110.6 & 67.5 & 29.5 \\
\hline \multirow{8}{*}{ 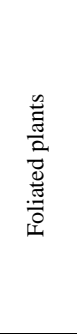 } & \multirow{4}{*}{$\begin{array}{c}\text { Un- } \\
\text { inoculation }\end{array}$} & 0 & 3.50 & 0.48 & 2.84 & 0.21 & 190.5 & 107.1 & 63.4 & 27.7 \\
\hline & & 150 & 3.70 & 0.55 & 3.15 & 0.30 & 196.1 & 112.9 & 67.9 & 30.6 \\
\hline & & 300 & 3.84 & 0.59 & 3.35 & 0.36 & 200.9 & 118.5 & 69.8 & 32.4 \\
\hline & & 450 & 3.95 & 063 & 3.41 & 0.39 & 205.5 & 121.4 & 72.5 & 34.9 \\
\hline & \multirow{4}{*}{ Inoculation } & 0 & 3.65 & 0.65 & 3.05 & 0.30 & 210.0 & 115.8 & 70.3 & 30.7 \\
\hline & & 150 & 4.19 & 0.68 & 3.45 & 0.38 & 217.4 & 119.7 & 73.7 & 34.8 \\
\hline & & 300 & 4.55 & 0.73 & 3.70 & 0.45 & 225.8 & 124.2 & 77.4 & 37.7 \\
\hline & & 450 & 4.67 & 0.76 & 3.84 & 0.51 & 230.6 & 127.8 & 79.6 & 39.5 \\
\hline \multirow{7}{*}{ 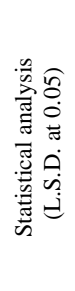 } & \multicolumn{2}{|c|}{ M } & 0.14 & 0.10 & 0.12 & 0.05 & 3.70 & 4.20 & 3.40 & 0.90 \\
\hline & \multicolumn{2}{|c|}{ I } & 0.13 & 0.06 & 0.10 & 0.04 & 2.10 & 1.70 & 2.20 & 1.70 \\
\hline & \multicolumn{2}{|c|}{$S$} & 0.12 & 0.07 & 0.13 & 0.05 & 2.50 & 2.50 & 2.50 & 1.10 \\
\hline & \multicolumn{2}{|c|}{ M x I } & 0.11 & 0.05 & 0.14 & 0.04 & 3.00 & 1.80 & 3.10 & 1.50 \\
\hline & \multicolumn{2}{|c|}{$M \times S$} & 0.17 & 0.05 & 0.09 & 0.05 & 4.80 & 3.40 & 2.20 & 1.00 \\
\hline & \multicolumn{2}{|c|}{ I x S } & 0.20 & 0.07 & 0.08 & 0.06 & 2.30 & 2.90 & 2.70 & 1.10 \\
\hline & \multicolumn{2}{|c|}{$M \times I \times S$} & 0.13 & 0.08 & 0.13 & 0.07 & 2.40 & 4.10 & 2.00 & 1.50 \\
\hline
\end{tabular}

$\mathrm{PDB}=\mathrm{P}$-dissolving bacteria, MFS=Micronutrients foliar spray, $\mathrm{SES}=$ Soil elemental sulphur.

The obtained results exhibited pronounced increases for the studied macronutrients due to the applied elemental sulphur as a solely treatment, with greatest values when it was combined with both PDB and MFS, followed the combined treatments of (ES+PDB) and (ES+MFS) as compared to the control treatment (untreated soil). Undoubtedly, the applied solely treatments were usefulness as compared to the combined one for the plant tissue contents of the studied nutrients. That was true, since the nutrients uptake by plants are more

Egypt. J. Soil Sci. 53, No. 2 (2013) 
related to the released available nutrients and their easily mobility towards the plant roots. Such surpassed effects were more associated with ameliorated soil $\mathrm{pH}$ due to the applied elemental sulphur and biological activity and their released active substances that enhancing nutrients solubilization from both native and added sources, besides the favourable biological conditions that are keeping them in available forms and their mobility for uptake by plant roots. In this concern, Abdallah et al. (2010) showed that S deficiency for field-grown oilseed rape can reduce nitrogen use efficiency (NUE: ratio of harvested $\mathrm{N}$ to $\mathrm{N}$ fertilization) and that $\mathrm{N}$ deficiency can also reduce sulphur use efficiency (SUE).

On the other hand, the micronutrient contents in plant tissues of canola as affected by the applied treatments were behaved another distribution pattern, i.e., the greatest values were associated with the triple treatment of $(\mathrm{ES}+\mathrm{PDB}+\mathrm{MFS})>$ $(\mathrm{ES}+\mathrm{MFS})>(\mathrm{ES}+\mathrm{PDB})>\mathrm{MFS}>\mathrm{PDB}$ as compared with the control treatment. Further, such favored better micronutrient uptakes are in harmony with the scientific fact the chelated micronutrients (-EDTA) represented the superior form due to a higher portion of these compounds still in maintained active forms for uptake by plant leaves. Such results are in agreement with those obtained by Soliman (1980) for Zn, Baza et al. (1989) for Fe and Basyouny (2005) for Mn and $\mathrm{Cu}$. Meanwhile, such favourable effect was extended to the combined treatments at the highest rate of $S(450 \mathrm{~kg} / \mathrm{fed}$, being insignificant difference with the S-rate of $300 \mathrm{~kg} \mathrm{~S} / \mathrm{fed}$ ) due to improving soil physico-chemical properties that positively affect the nutrients availability as well as maintaining a suitable soil moisture regime, which showed a pronounced positive effect on the biological activity in soil. Also, the integrated action of the bio-fertilizer and Stransformation to $\mathrm{H}_{2} \mathrm{SO}_{4}$, besides the possible released phosphate ions by sulfate ions was, in general, extending parallel close to the corresponding nutrient contents in the plant tissues (El-Tapey and Hassan, 2002).

It is noteworthy to mention that a significant increase in each of the studied nutrient content of canola plant tissues at 85 days from sowing was observed with the application of S combined with either PDB or MFS. However, the successive additions of $\mathrm{S}$ rates with or without PDB or MFS, may be enhanced root activity for nutrients uptake. Also, a significant increase in nutrient contents of shoot plant tissues was observed with increased the released $\mathrm{P}$ due to the application of PDB. These results are supported by the findings of Kasturikrishan and Ahlawat (1999), who reported that a significant interaction effect of $(\mathrm{P} \times \mathrm{S} \times \mathrm{Zn})$ was observed for nutrient contents in the canola plant tissues. Moreover, the interaction between $S$ and PDB was significant and the best combination dose was $S_{450}$, with insignificant difference with $S_{300}$, which gave the maximum nutrient contents. This confirms the synergism between P and S (Varavipur et al., 1999). Such results confirmed the synergistic relationship of $\mathrm{S}$ and $\mathrm{P}$, which may be attributed to the promotion of root development by $\mathrm{P}$ that has been found to induce higher uptake of native applied sulphur. 


\section{b. Plant growth characters}

Data presented in Table 7 indicate that the achieved favourable soil conditions due to the applied treatments, particularly the combined ones of elemental sulphur with either bio-fertilizer (PDB) or foliated with micronutrients (MFS), were positively reflected on the studied values of canola plant growth characters (i.e., leaf chlorophyll a\&b, plant height, No. of branches plant ${ }^{-1}$, dry matter weight plant ${ }^{-1}$ and fruiting zone length) as compared to the applied solely ones. It can be explained on the basis that the treated soil with elemental sulphur and bio-fertilizer (PDB) became enriched in the released nutrient contents, especially those of micronutrients, which are involved directly or indirectly in formation of biological components through their roles in the respiratory and photosynthesis mechanisms as well as in the activity of various enzymes (Nassar et al., 2002). Also, the promotive effect of the applied treatments on leaf chemical constituents might be attributed to their enhancing effect on the nutritional status of canola plants, and then the increase in dry weight of shoot/plant that could be attributed to its stimulating effect on vegetative growth and physiological processes, i.e. increasing number of cells through cell division and meristematic activity of tissues. In addition, the increase of total chlorophyll is owing to that the enhanced nutrients uptake plays an important role for stimulating chlorophyll synthesis enzymes, which reflected on formation of chlorophyll molecule (Abdel-Aziz and El-Shafie, 2005).

Further, it could noticed that the obtained values of the studied plant growth characters tended to gradual increase with increasing the applied rates of elemental sulphue from 0 up to $450 \mathrm{~kg} / \mathrm{fed}$, with insignificant difference between 300 and $450 \mathrm{~kg} \mathrm{~S} / \mathrm{fed}$. Also, it is noteworthy to mention that the applied triple treatment of elemental sulphur as a soil amendment at the highest rate $(450 \mathrm{~kg} / \mathrm{fed})$ in combination with bio-fertilizer (PDB) plus foliated with micronutrients (MFS) was achieved the greatest values of the tested plant growth characters, with insignificant difference with the applied S-rate of $300 \mathrm{~kg} / \mathrm{fed}$. That was true, since treated soil with elemental sulphur during preparing process for canola cultivation in combination with a seed inoculation with P-dissolving bacteria enhancing and sustaining the increase in the values of germination rate, shoot and radical lengths. In this concern, the increase in dry matter weight of whole plant due to sulphur application can be explained as to enhance cell division and capacity of sulphur cell elongation or expansion. It is also interpreted to have favourable effect of chlorophyll synthesis resulting in more number of leaves with bigger size and higher chlorophyll content. Thus, sulphur helps in increasing the photosynthetic activity of plant (Upasami and Shama, 1986). Also, the number of branches/plant was substantially improved by the released $\mathrm{P}$ due the applied elemental sulphur and P-dissolving bacteria. Such stimulatory effect might lead to increase in all the yield attributes. These results are in accordance with the findings of Thakur and Chand (1998), who found that P fertilization increased the growth parameters of canola plants. 
SIGNIFICANCE OF ELEMENTAL SULPHUR, BIO-INOCULATION...

TABLE 7. Effect of elemental sulphur, bio-inoculation and micronutrients foliar spray applied treatments on some plant growth characters.

\begin{tabular}{|c|c|c|c|c|c|c|c|c|}
\hline \multirow[t]{2}{*}{$\begin{array}{l}\text { MFS } \\
(\mathbf{M})\end{array}$} & \multirow[t]{2}{*}{$\begin{array}{l}\text { PDB } \\
\text { (I) }\end{array}$} & \multirow{2}{*}{$\begin{array}{l}\text { Elemental } \\
\text { sulphur, S } \\
\left(\mathbf{k g ~ f e d ~}^{-1}\right)\end{array}$} & \multicolumn{2}{|c|}{$\begin{array}{l}\text { Leaf chlorophyll } \\
\text { (mg/g fresh } \\
\text { weight) }\end{array}$} & \multirow{2}{*}{$\begin{array}{l}\text { Plant } \\
\text { height } \\
(\mathbf{c m})\end{array}$} & \multirow{2}{*}{$\begin{array}{c}\text { No. of } \\
\text { branches } \\
\text { plant }^{-1}\end{array}$} & \multirow{2}{*}{$\begin{array}{l}\text { Dry } \\
\text { matter } \\
\text { weight }^{-1} \\
\text { plant }^{-1}\end{array}$} & \multirow{2}{*}{$\begin{array}{c}\text { Fruiting } \\
\text { zone } \\
\text { length } \\
(\mathrm{cm})\end{array}$} \\
\hline & & & $\mathbf{a}$ & B & & & & \\
\hline \multirow{8}{*}{ 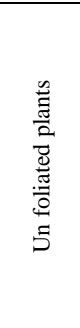 } & \multirow{4}{*}{$\begin{array}{l}\text { Un- } \\
\text { inoculation }\end{array}$} & 0 & 0.540 & 0.269 & 137.4 & 7.3 & 84.5 & 52.7 \\
\hline & & 150 & 0.691 & 0.324 & 148.0 & 9.4 & 109.3 & 57.4 \\
\hline & & 300 & 0.752 & 0.358 & 155.1 & 10.8 & 125.9 & 60.8 \\
\hline & & 450 & 0.763 & 0.374 & 156.9 & 11.4 & 127.1 & 62.5 \\
\hline & \multirow{4}{*}{ Inoculation } & 0 & 0.617 & 0.293 & 140.2 & 9.5 & 94.9 & 61.0 \\
\hline & & 150 & 0.763 & 0.365 & 158.6 & 11.1 & 118.7 & 69.2 \\
\hline & & 300 & 0.861 & 0.425 & 170.1 & 13.2 & 135.0 & 74.7 \\
\hline & & 450 & 0.875 & 0.438 & 172.4 & 13.2 & 136.7 & 76.0 \\
\hline \multirow{8}{*}{ 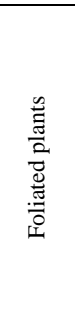 } & \multirow{4}{*}{$\begin{array}{c}\text { Un- } \\
\text { inoculation }\end{array}$} & 0 & 0.602 & 0.289 & 139.5 & 8.9 & 92.4 & 60.2 \\
\hline & & 150 & 0758 & 0.354 & 156.8 & 10.7 & 117.8 & 67.9 \\
\hline & & 300 & 0.849 & 0.409 & 168.9 & 11.8 & 134.8 & 73.3 \\
\hline & & 450 & 0.852 & 0.425 & 171.5 & 12.9 & 135.5 & 74.8 \\
\hline & \multirow{4}{*}{ Inoculation } & 0 & 0.624 & 0.379 & 143.1 & 10.5 & 109.6 & 67.4 \\
\hline & & 150 & 0.789 & 0.416 & 166.0 & 12.7 & 128.4 & 74.8 \\
\hline & & 300 & 0.897 & 0.465 & 181.4 & 14.8 & 141.5 & 79.7 \\
\hline & & 450 & 0.915 & 0.487 & 183.7 & 15.2 & 143.7 & 81.3 \\
\hline \multirow{7}{*}{ 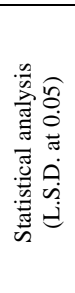 } & \multicolumn{2}{|c|}{$M$} & 0.022 & 0.046 & 7.87 & 0.57 & 2.20 & 0.90 \\
\hline & \multicolumn{2}{|c|}{ I } & 0.018 & 0.037 & 9.26 & 0.76 & 3.90 & 1.10 \\
\hline & \multicolumn{2}{|c|}{$\mathrm{S}$} & 0.020 & 0.042 & 5.25 & 0.70 & 1.70 & 2.00 \\
\hline & \multicolumn{2}{|c|}{ M x I } & 0.037 & 0.074 & 8.53 & 0.64 & 4.70 & 1.70 \\
\hline & \multicolumn{2}{|c|}{$\mathrm{MxS}$} & 0.026 & 0.054 & 6.93 & 0.63 & 1.10 & 0.70 \\
\hline & \multicolumn{2}{|c|}{ Ix S } & 0.034 & 0.070 & 7.87 & 0.45 & 2.10 & 1.80 \\
\hline & \multicolumn{2}{|c|}{$M \times I \times S$} & 0.030 & 0.062 & 5.98 & 0.57 & 3.40 & 1.00 \\
\hline
\end{tabular}

$\mathrm{PDB}=\mathrm{P}$-dissolving bacteria, MFS=Micronutrients foliar spray, SES=Soil elemental sulphur.

Moreover, such combination is more attributed to enrich in both bio- and mineral-substances that are essential to plant growth, stimulating and activating the bio-chemical processes in plant organs, i.e., respiration, photosynthesis, chlorophyll content, vital enzymes and hormonal stimulating, which increasing photosynthetic activity. Such favourable conditions of soil fertility was reflected on the studied plant growth characters of the grown canola plants, owing to such applied bio-fertilizer and inorganic soil amendments are not only improving soil fertility status but also assisting canola plants to tolerant soil salinity/sodicity. In addition, combining bio-fertilizer with sulphur that led to a markedly increase in the tested growth characters, may be due to their outcomes are essentially for creation of protoplasm, and hence producing new cells and new leaves of canola plants that lead to a larger leaf area available for photosynthesis and increase dry matter accumulation (Omran and Azzam, 2007). 


\section{c. Yield and its attributes}

Data presented in Table 8 reveale that the number of pods/plant, biological yield (seed and straw yields) and some parameters of seed quality (1000 seed weight, protein and oil contents \%) were substantially improved by the application of elemental sulphur in combination with either P-dissolving bacteria (PDB) or foliated micronutrients of DTPA-chelated Fe, Mn, $\mathrm{Zn}$ and $\mathrm{Cu}$. That means, the aforementioned best vegetative growth characters were positively reflected on canola yield and its attributes and returned on increasing both No. of pods plant ${ }^{-1}$ and seed yield as well as their quality parameters (i.e., 1000 seed weight, seed contents of protein and oil \%) as shown in Tables 7 and 8 .

TABLE 8. Effect of elemental sulphur, bio-inoculation and micronutrients foliar spray applied treatments on canola yield and its attributes.

\begin{tabular}{|c|c|c|c|c|c|c|c|c|}
\hline \multirow[b]{2}{*}{$\begin{array}{c}\text { MFS } \\
(\mathbf{M})\end{array}$} & \multirow[b]{2}{*}{$\begin{array}{c}\text { PDB } \\
\text { (I) }\end{array}$} & \multirow[b]{2}{*}{$\begin{array}{c}\text { Elemental } \\
\text { sulphur, } S \\
\left(\mathrm{~kg} \mathrm{fed}^{-1}\right)\end{array}$} & \multirow[b]{2}{*}{$\begin{array}{c}\text { No. of } \\
\text { pods } \\
\text { plant }^{-1}\end{array}$} & \multicolumn{2}{|c|}{ Biological yield } & \multicolumn{3}{|c|}{ Seed quality parameters } \\
\hline & & & & 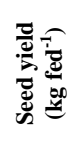 & 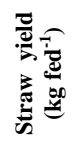 & 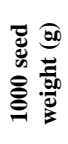 & 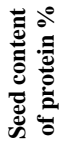 & 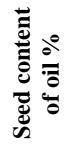 \\
\hline \multirow{8}{*}{ 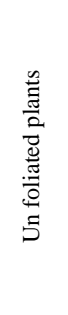 } & \multirow{4}{*}{$\begin{array}{l}\text { Un- } \\
\text { inoculation }\end{array}$} & 0 & 167.5 & 352.4 & 523.8 & 1.54 & 28.9 & 36.5 \\
\hline & & 150 & 191.2 & 405.3 & 600.4 & 2.04 & 29.1 & 37.3 \\
\hline & & 300 & 207.0 & 440.5 & 651.2 & 2.37 & 29.7 & 37.9 \\
\hline & & 450 & 209.2 & 445.6 & 657.9 & 2.41 & 30.3 & 38.6 \\
\hline & \multirow{4}{*}{ Inoculation } & 0 & 204.8 & 402.5 & 601.0 & 2.05 & 30.0 & 38.7 \\
\hline & & 150 & 221.5 & 467.6 & 693.8 & 2.40 & 30.9 & 40.4 \\
\hline & & 300 & 232.7 & 511.0 & 755.6 & 2.64 & 31.5 & 41.1 \\
\hline & & 450 & 234.0 & 513.5 & 758.2 & 2.68 & 32.6 & 42.0 \\
\hline \multirow{8}{*}{ 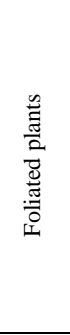 } & \multirow{4}{*}{$\begin{array}{l}\text { Un- } \\
\text { inoculation }\end{array}$} & 0 & 196.5 & 395.4 & 597.2 & 1.97 & 29.2 & 37.9 \\
\hline & & 150 & 213.7 & 461.7 & 682.6 & 2.30 & 30.0 & 38.6 \\
\hline & & 300 & 225.1 & 505.3 & 739.6 & 2.52 & 30.5 & 39.0 \\
\hline & & 450 & 227.8 & 508.7 & 743.4 & 2.57 & 31.9 & 40.7 \\
\hline & \multirow{4}{*}{ Inoculation } & 0 & 223.0 & 434.0 & 658.7 & 2.25 & 31.8 & 41.2 \\
\hline & & 150 & 246.2 & 50.9 .4 & 759.2 & 2.68 & 33.1 & 42.8 \\
\hline & & 300 & 261.4 & 559.2 & 826.2 & 2.97 & 34.0 & 43.9 \\
\hline & & 450 & 264.7 & 563.9 & 832.6 & 3.05 & 35.8 & 45.1 \\
\hline \multirow{7}{*}{ 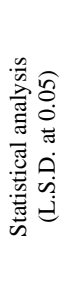 } & \multicolumn{2}{|c|}{ M } & 12.70 & 3.50 & 12.10 & 0.38 & 0.90 & 1.10 \\
\hline & \multicolumn{2}{|c|}{ I } & 10.50 & 4.10 & 11.70 & 0.46 & 1.70 & 1.70 \\
\hline & \multicolumn{2}{|c|}{$\mathrm{S}$} & 11.50 & 2.90 & 10.90 & 0.56 & 1.10 & 1.00 \\
\hline & \multicolumn{2}{|c|}{ M x I } & 21.20 & 4.00 & 13.20 & 0.48 & 0.70 & 1.10 \\
\hline & \multicolumn{2}{|c|}{$M \times S$} & 14.90 & 3.70 & 9.50 & 0.56 & 1.00 & 1.00 \\
\hline & \multicolumn{2}{|c|}{ Ix S } & 19.50 & 4.90 & 10.0 & 0.51 & 0.90 & 0.90 \\
\hline & \multicolumn{2}{|c|}{$M \times I \times S$} & 17.10 & 2.50 & 13.9 & 0.38 & 1.10 & 0.80 \\
\hline
\end{tabular}

$\mathrm{PDB}=\mathrm{P}$-dissolving bacteria, $\mathrm{MFS}=$ Micronutrients foliar spray, $\mathrm{SES}=$ Soil elemental sulphur .

Egypt. J. Soil Sci. 53, No. 2 (2013) 
In general, the optimum canola seed yield with high quality parameters were extending parallel close to the corresponding soil available nutrient contents and vegetative growth characters, as shown in Tables 5, 7 and 8 . The stimulatory effects of $\mathrm{S}$ in combination with either PDB or MFS on canola growth might lead to increase in all yield and its attributes. These results are in accordance with the findings of Thakur and Chand (1998) who found that the released P increased seed and straw yields, which were favourable affected due to the improvement of the growth parameters and yield attributes of canola plants. Also, yield attributes like number of pods/plant and 1000 seed weight were substantially improved due to the combined application of S and MFS. These results are also in the line with those obtained by Aly (2003) who stated that the pronounced bacterial activity, due to the applied bio-fertilizer and inorganic soil amendments such as elemental sulphur, is capable to produce some hormones which induces the proliferation roots and root hair that increase nutrient absorbing surfaces as well as produce organic acids, which solublize inorganic and organic forms of mineral elements, and consequently increase stems and leaves then the pods plant ${ }^{-1}$ and seed yields.

The 1000 seed weight was increased steadily by graded applied rates of elemental sulphur combined with either PDB or MFSP. There was concomitant increase in 1000 seed weight by application of $S$ at a rate of $450 \mathrm{~kg} / \mathrm{fed}$, with insignificant difference between $S_{450}$ and $S_{300}$ /fed. From the economical point of view, the interaction effects of (PDB x S), (PDB x MFS) and (S x MFS) were significant, and the best combination doses were (PDB x $\mathrm{S}_{300}$ ), (PDB x MFS) and $\left(S_{300} \times \mathrm{MFS}\right)$ and (PDB $\left.\times \mathrm{S}_{300} \times \mathrm{MFS}\right)$. However, a significant response for canola seed yield was seen to the applied $S$ with either PDB or MFS. The seed yield of $352.4 \mathrm{~kg} / \mathrm{fed}$ was obtained at the treatment of $\left(\mathrm{S}_{0} \times \mathrm{PDB}_{0} \times \mathrm{MFS}_{0}\right)$, and increased to a greatest amount of $543.9 \mathrm{~kg} / \mathrm{fed}$ at $\left(\mathrm{S}_{450} \times \mathrm{PDB} \times \mathrm{MFS}\right)$ treatment, as shown in Table 8.

The biological yield of canola responded fovourably with increasing the $S$ rates up to $450 \mathrm{~kg} \mathrm{~S} / \mathrm{fed}$ plus $\mathrm{PDB}$, with in significant difference with $\mathrm{S}_{300}$, indicating higher needs of $\mathrm{P}$ and $\mathrm{S}$ by the crop. Such increases in seed and straw yields (biological yield) with applied $S$ alone or in combination with either PDB or MFS were emphasized by the findings outlined by Bolland (1997) who reported that canola may require a higher $\mathrm{P}$ content in seed to supply the germinating seedling with enough $\mathrm{P}$ during the early stages of plant growth before the roots have developed, sufficiently to take up significant amount of $\mathrm{P}$ from the soil. However, $\mathrm{P}$ is needed during the earliest stage of plant growth, yet any $\mathrm{P}$ deficiency during early growth can greatly reduce yield potential of tops and seeds. Therefore, the amount of released P due to bio-inoculation with PDB in canola seed could be important to help seedling establishment and in determining final seed yield.

The positive response of canola yield and its attributes to sulphur application was associated with the applied rates of 300 and $450 \mathrm{~kg} \mathrm{~S} / \mathrm{fed}$. Such response 
was optimized when S was combined with either PDB or MFS. Similar results are observed by Malhi and Gill (2002 \& 2006) and Malhi et al. (2006) who reported that all Brassica oilseed species/cultivars responded positively for seed yield and most other parameters to $\mathrm{S}$ application. The effect of $\mathrm{S}$ deficiency and applied $\mathrm{S}$ were more pronounced on seed than straw. They also suggest that $\mathrm{S}$ application rates for all seed yield should be similar for the B-oilseed species/cultivars used on S-deficient soil, but higher yielding types would produce greater seed yield by using $\mathrm{S}$ more efficiently.

Data presented in Table 8 showed a positive response for each of all yield components, seed and straw yields of canola plants to foliated micronutrients, especially in the presence of S and PDB. The obtained results showed that the seed yield and its attributes of canola had been found to be significantly increased due to solely and combined treatments of S, PBD and MFS, being recorded the greatest yield at the combined treatment of ( $\left.\mathrm{S}_{450} \times \mathrm{PDB} \times \mathrm{MFS}\right)$ over that absolute control $\left(\mathrm{S}_{0} \times \mathrm{PDB}_{0} \times \mathrm{MFS}_{0}\right)$. Such greater increases in seed yield and its attributes due to the applied previous combined treatment might be due to higher availability of $\mathrm{S}, \mathrm{P}$ and micronutrients in the soil with the simultaneous greater absorption imparting growth and seed yield. Similar results also reported by Das et al. (2004). Although the sole application of S, PDB and MFS gave relatively higher values of canola yield and its attributes, but their combined treatments showed further more values.

Regarding the interaction between S, PDB and MFS application, there was a significant effect at both rates of $S_{300}$ and $S_{450} /$ fed in combination with either PDB or MFS. These applied treatments enhance dry matter, seed yield and yield components of canola, however, the maximum dry matter yield at flowering stage, seed yield and yield components were achieved at $S_{300}$ and $S_{450} / f e d$ in combination with PDB followed by MFS. The greatest seed yield of 563.9 $\mathrm{kg} / \mathrm{fed}$, which was obtained under the abovementioned (S x PDB x MFS) at $\mathrm{S}_{300^{-}}$ $\mathrm{S}_{450}$ rates, achieved a relative increase percentage of 58.12-60.02\% over the control treatment. This was more related to largely greater numbers of pods and branches/plant.

The favourable effect of the applied combinations may be due to maintaining a best balance between $\mathrm{P}$ and micronutrients in the canola plant for optimum growth. These results are in agreement with those obtained by Lu-Zhong et al. (1998) who noted a significant increase in straw of canola plant with application of $\mathrm{P}$ and micronutrients. On the other hand, best values of canola yield and its attributes due to the combined application of S and micronutrients, mainly due to the higher biomass production. However, the improvement in canola yield and its attributes due to application of ( $\mathrm{S}$ plus MFS) resulted in proportionately similar increase in seed and straw yields. These results confirm those obtained by Das et al. (2004).

Egypt. J. Soil Sci. 53, No. 2 (2013) 
As shown in Table 8, protein and oil contents in canola seed were increased significantly with increasing $S$ rates up to $450 \mathrm{~kg} / \mathrm{fed}$, with insignificant difference between $S_{450}$ and $S_{300} /$ fed. Synthesis of fatty acids in plant occurs through conversion of acetyl Co-A to maloney Co-A in presence of ATP and phosphate (Bonner and Varner, 1965). Similarly of released P was elevated protein content in seed may be due to more protein synthesis in the presence of $\mathrm{P}$ and the formation of some stable phospho-protein compounds. These results are in harmony with those obtained by Patel and Shelk (1998). The obtained data also revealed that the amount of protein content was gradually increased as a function of successive additions of elemental sulphur. Also, the response of seed oil content to $\mathrm{S}$ application was particularly significant at the applied S-rates 300 and $450 \mathrm{~kg} / \mathrm{fed}$. In this connection, Lal et al. (1995) showed that S application resulted in significant increase in seed oil content, since $S$ is an integral part of acyl-Co-enzyme A that helps synthesis of more fatty acids.

The highly significant enhancement of $\mathrm{S}$ on the oil content of canola seed due to it represents an essential component in some essential amino acids such as cystein and methionine for protein synthesis (Anderson, 1990 and Malhi, 2006). Also, Patel and Shelke (1998) reported that the possible explanation in increased oil and protein contents in seed was that, $\mathrm{S}$ is directly, involved in oil synthesis and protein metabolism. Sulphur fertilization does not only improved the quality of oil crop product and increase its market value, particularly in the case of rapeseed, but also it plays an important role in protein synthesis, and thus affected $\mathrm{N}$-use and metabolism in plant (Messick and Fan, 1999). Depending upon the presented Data in Table 8, protein and oil contents of canola seed have been found to be optimized in case of combinations with MFS application. Similar results were observed by Das et al. (2004). Being greater magnitude of 23.87 and $23.56 \%$ was occurred at the combined treatment of $\left(\mathrm{S}_{450} \times \mathrm{PDB} \times \mathrm{MFS}\right)$ for seed contents of protein and oil, respectively, mainly due to greater stimulating action of some applied micronutrients in the synthesis of $\mathrm{S}$ containing protein and also localization of micronutrients in protein bodies as discrete particularly in seed as well as higher rate of translocation of them in presence of $S$ from the root to seed via shoot meristem resulting increased tranciption and transaction with reduced rate of RNA degradation (Sharma et al., 1990).

It is noteworthy to mention that data obtained are of the importance in such studied saline-alkaline sandy clay loam soil calcareous in nature, owing to the effective role of the used inorganic substance of elemental sulphur plus biofertilizer, which was not only exerted a positive effect on soil fertility status, but also on the different soil properties. Such amelioration in physical, chemical and biological was reflected positively on the canola seed yield with high quality as well as chemical constituents of seed (seed contents of protein and oil). Also, the applied such bio-fertilizer and inorganic soil amendments had a long-term positive agronomic value due to its capacity to gradually liberate available plant nutrients and to improve soil characteristics. The integrated supply of nutrients through bio-organic and inorganic sources could be an effective practice of 
nutrient management. Moreover, this approach is not only assist a suitable income farmers due to increasing plant production with adverseable of soil calcareous in nature, but also alleviate the potential hazardous of both soil salinity and sodicity conditions.

\section{References}

Abdallah, M., Dubousset, L., Meuriot, F., Etienne, P., Avice, J.C. and Ourry, A. (2010) Effect of mineral sulphur availability on nitrogen and sulphur uptake and remobilization during the vegetative growth of Brassica napus L. Journal of Experimental Botany 123: 1-12.

Adel Aziz, El-Set and El-Shafie, A.I. (2005) Response of soybean to foliar application of phosphatic fertilizer and some micronutrients. Egypt J. Appl. Sci. 20 (5B): 696-719.

Abdel Aziz, S.M., Mostafa, M.A., Basyouny, E.A. and Yousef, E.G. (2002) Relationship between chemical forms of micronutrients in soils amended with organic materials and their uptake by plants. Egypt. J. Appl. Sci. 17 (11): 700-717.

Anderson, J.W. (1990) Sulphur metabolism in plant. In: "Biochemistry of Plant", (Vol. 16, Intermediary Nitrogen Metabolism) B.J. Miflin and P.J. Lea (Ed.), pp. 327-381, Academic Press, San Diago, CA, USA.

Aly, Mona M.M. (2003) Biological studies on some associative nitrogen fixing bacteria. M. Sc. Thesis, Fac. of Agric., Cairo Univ., Giza, Egypt.

A.O.A.C. (1995) "Official Methods of Analysis", 12 $12^{\text {th }}$ ed., Association of Official Analytical Chemists, Washington, D.C.

Ashmaye, S.H., Shaban, Kh.A. and Abd El-Hader, M.G. (2008) Effect of mineral nitrogen, sulphur, organic and bio-fertilizers on maize productivity in saline soil of Sahl El-Tina. Minufiya J. Agric. Res. 33 (1): 195-209.

Awadalla, A.A., Salib, M.M. and Ibrahim, S.B. (2003) Response of maize yield grown on calcareous soil to some organic and inorganic amendments under irrigation with saline drainage water. Egypt. J. Appl. Sci. 18 (3): 366-381.

Azer, Sohair A., Awad, M.A., Sadek, Jaklin G., Khalil, F.A. and El-Aggory, Eglal M.A. (2003) A comparative study on the effect of elemental $S$ and biophosphatic fertilizers on the response of faba bean to P fertilization. Egypt. J. Appl. Sci. 18: 324-363.

Azzam, Clara R. and Omran, Samya E.H. (2005) The promotive effect of PDB biofertilizer on growth, enzymatic activity and bio-chemical changes of sunflower (Helianthus annuus L.) plants sprayed with micronutrients. The $3^{\text {th }}$ Conf. of Recent Technologies in Agric. Fac. of Cairo Univ., Giza, 14-16 November, No 2: 255-267.

Basyouny, E.A. (2005) Effect of chelated micronutrients combined with sulphur or organic manures on wheat production grown on calcareous soil. Egypt. J. Appl. Sci. 20 (9): 375-387. 
Baza, M.S., Monged, N.O. and Mohamed, K.S. (1989) Response of faba bean to foliar application of some micronutrient treatments. J. Agric. Sci., Mansoura Univ. 14: 884892.

Bidwell, R.G.S. (1979) "Plant Physiology", $2^{\text {nd }}$ ed., 726 p., Macillan Publishing Co-Inc., New York, NY.

Black, C.A., Evans, D.D., Ensminger, L.E., White, J.L. and Clark, F.E. (1965) "Methods of Soil Analysis", Amer. Soc. Agron., Inc. Pub., Madison, Wisconsin, USA.

Bolland, M.D.A. (1997) Comparative phosphorus requirement of canola and wheat. $J$. Plant Nutr. 20: 813-829.

Bonner, J. and Varner, J.E. (1965) "Plant Biochemistry", 925 p., Academic Press, New York.

Ceccotti, S.P. (1996) Plant nutrient sulphur. A review of nutrient balance, environmental impact and fertilizers. Fertilizers Res. 43:117-125.

Cheema, M.A., Malik, M.A., Hussain, A., Shah, S.H. and Basra, M.A. (2001) Effects of time and rate of nitrogen and phosphorus application on the growth and seed and oil yield of canola. Agron. and Crop Sci. 18: 103-110.

Chapman, H.D. and Pratt, P.F. (1961) "Methods of Analysis for Soils, Plants and Waters", Univ. of California, Riverside, U.S.A.

Das, D.K., Chakrabortry, A.K., Maite, D. and Puste, A.M. (2004) Interaction between $\mathrm{Zn}$ and $\mathrm{S}$ on their availability in soils. Proceedings of the $4^{\text {th }}$ the International Crop Science, Brisbane, Australia, 26 Sept.- 10 Oct., 2004.

El-Kabbany, E.A.Y., Mahrous, M.A., Hamada, A.A. and Darwech, A.A. (1996) Response of wheat to foliar application zinc, iron and copper. Proc. $7^{\text {th }}$ Conf. Agron., 9-10 Sep., pp. 1-9.

El-Fayoumy, M.E. and Ramadan, H.M. (2002) Effect of bio-organic manures on sandy soils amelioration and peanut productivity under sprinkler irrigation system. Egypt. J. Soil Sci. 42 (3): 383.

El-Tapey, H.M.A. and Hassan, H.M. (2002) Effect of water salinity and zinc applications on zinc mobility and growth of sunflower and sudangrass plants grown on Nile alluvial and calcareous soils. Egypt. J. Appl. Sci. 17 (12): 840-849.

Grant, C.A. and Bailey, L.D. (1993) Interaction of zinc with banded and broadcast phosphorus fertilizer on the concentration and uptake of $\mathrm{P}, \mathrm{Zn}, \mathrm{Ca}$ and $\mathrm{Mg}$ in plant tissue of oilseed flax-candian. J. of Plant Sci. 73: 17-29.

Haneklaus, S., Paulsen, H.M., Gupta, A.K., Bloem, E. and Schnug, E. (1999) Influence of sulphur fertilization on yield and quality of oilseed rape and mustard. Proceedings of the $10^{\text {th }}$ International Rapeseed Congress, Australia.

Hesse, P.R. (1971) "A Text-Book of Soil Chemical Analysis", John Murray, London, Great Britain. 
Issam, I.B. and Sayegh, A.H. (2007) "Methods of Analysis for Soils of Arid and Semiarid Regions", F.A.O. Rome, Italy.

Jackson, M.L. (1973) "Soil Chemical Analysis", Prentice Hall of India, Private Limited, New Delhi, Indian.

Kaplan, M., Orman, S., Kadar, I. and Koncz, J. (2005) Heavy metal accumulation in calcareous soil and sorghum plants after addition of sulphur-containing wastes as a soil amendment in Turkey. Agric. Ecosyst. Environ. 111: 41-46.

Kasturikrishan, S. and Ahlawat, I.P.S. (1999) Growth and yield response of pea (Pisum sativum) to moisture stress, phosphorus, sulphur and zinc fertilizers. Indian J. of Agron. 44: 588-596.

Kelly, J.D. and Bliss, F.A. (1975) Habitability estimated of percentage seed protein and available methionine and correlations with yield in dry bean. Crop Sci. 15: 753-757.

Lal, N., Sarawgi, S.K., Tripathi, R.S. and Bhambri, M.C.B. (1995) Effect of nitrogen, potassium and sulphur on seed yield, nutrient uptake, quality and economics of summer sesame. Indian J. Agron. 40: 333-335.

Lindsay, W.L. and Norvell, W.A. (1978) Development of DTPA soil test for Zn, Fe, Mn and Cu. Soil Sci. Soc. Am. J. 42 , 421.

Lu-Zhong, G., Grewal, H.S. and Graham, R.D. (1998) Dry matter production and uptake of zinc and phosphorus in two oilseed rape genotypes under differential rates of zinc and phosphorus supply. J. of Plant Nutr. 21: 25-38.

Malhi, S.S. (2006) Sulphur fertilizer management for optimum seed yield and quality of canola in the candian great plains. The $18^{\text {th }}$ World Congress of Soil Science, July 9-15, 2006.

Malhi, S.S., Gan, Y. and Raney, J.P. (2007) Yield seed quality and sulphur uptake of Brassica oilseed crops in response to sulphur fertilization. Agron. J. 99: 570-577.

Malhi, S.S. and Gill, K.S. (2002) Effectiveness of sulphate-S fertilization at different growth stages for yield seed quality and S uptake of canola. Can. J. Plant Sci. 82: 665-674.

Malhi, S.S. and Gill, K.S. (2006) Cultivar and fertilizer S rate interaction effects on canola yield, seed quality and S uptake. Can. J. Plant Sci. 86: 91-98.

Marschner, H. (1986) "Mineral Nutrient of Higher Plants", Academic Press, New York, USA.

Messick, D.L. and Fan, M.X. (1999) The role of sulphur fertilizer in oil crop production. The IFA Regional Conference for Asia and the Pacific, 14-17. Kuala Lumpur, Malaysia.

Mohammed, S.S. (2004) Assessment of the relative effectiveness for some organic materials conjucted with mineral nitrogen on soil fertility status, yield and quality of wheat grown on a newly cultivated soil. Egypt. J. Appl. Sci. 19 (3): 298-310.

Egypt. J. Soil Sci. 53, No. 2 (2013) 
Moussa, B.I.M., Dahdoh, M.S.A. and Shehata, H.M. (1998) Interaction effect of some micronutrients on yield, elemental composition and oil content of peanut. Comm. Soil Sci. Plant Anal. 27 (2-8): 1995.

Mrkovacki, N. and Milic, V. (2001) Use of Azotobacter chroococcum as potentially useful in agricultural application. Ann. Microbiology 51: 145-158.

Nassar, K.E., Osman, A.O., El-Kholy, M.H., Madiha, M. and Badran, N. (2002) Effect of seed coating with some micronutrients on faba bean (Vicia faba L.).ll. Effect on yield attributes and mineral composition. Egypt. J. Soil Sci. 42 (3): 363.

Negm, A.Y. and Zahran, F.A. (2001) Optimization time of micronutrient application to wheat plants grown on sandy soils. Egypt. J. Agric. Res. 79 (3): 813-823.

Omran, Samya E.H. and Azzam, Clara R. (2007) Effect of sulphur, inoculation with Pdissolving bacteria and P-foliar application on two canola (Brassica napus L.) varieties. Egypt. J. Soil Sci. 47 (4): 321-333.

Page, A.L., Miller, R.H. and Keeney, D.R. (1982) "Methods of Soil Analysis. Part 2: Chemical and Microbiological Properties", $2^{\text {nd }}$ ed., Amer Soc. of Agron., Madison, Wisconsin, USA.

Patel, J.R. and Shelke, R.B. (1998) Effect of farmyard manure, phosphorus and sulphur on growth, yield and quality of Indian mustard (Brassica Juncea). Indian J. of Agron. 43: 713-717.

Ranganna, S. (1972) "Manual of Analysis of Fruit and Vegetable Products", pp. 80-82, Teta McGraw-Hill Pub. Co. Lim., New Delhi.

Shaban, Kh.A. and Omar, M.N.A. (2006) Improvement of maize yield and some soil properties by using nitrogen mineral and PGPR Group fertilization in newly cultivated saline soils. Egypt. J. Soil Sci. 46 (3): 329-342.

Sharma, U.C., Gangwar, M.S. and Shrivastava, P.C. (1990) Effect of zinc and sulphur on nutrient uptake and yield of mustard. J. Indian Soc. Soil Sci. 38: 696-701.

Snedecor, G.W. and Cochran, W.G. (1980) "Statistical Methods". $7^{\text {th }}$ ed., Iowa State Univ. Press, Ames, Iowa, USA.

Soliman, M.F. (1980) Zinc uptake by wheat plants as influenced by nitrogen fertilizers and calcium carbonate. Agric. Res. Rev. 58, 113.

Sys, C. and Verheye, W. (1978) An attempt to the evaluation of physical land characteristics for irrigation to the FAO framework for land evaluation. Int. 1, Trai. Cent. Post Grad. Soil Sci., Ghent, Belgium.

Sys, C., Van Ranst, E., Debaveye, J. and Beernaert, F. (1993) Land evaluation. Part III., Crop Requirements Agricultural Publication No.7, General Administration for Development Cooperation, Ghent, Belgium.

Tabatabai, M.A. and Bremner (1970) A simple turbidimetric method of determining total sulphur in plant materials. Agron. J. 62: 60-67.

Egypt. J. Soil Sci. 53, No.2 (2013) 
Thakur, K.S. and Chand, J. (1998) Response and economics in relation to nitrogen and phosphorus nutrition in gobhisaron (Brassica napus L.) under rainfed condition. Indian J. Agron. 43: 733-737.

Upasami, R.R. and Shama, H.C. (1986) Effect of nitrogen and sulphur on some growth parameters, evapotranspiration moisture use efficiency of mustard under dry land conditions. Indian J. Agron. 31: 222-228.

USDA (2010) "Key to Soil Taxonomy", $11^{\text {th }}$ ed., United States Department of Agriculture, USA.

Varavipur, M., Hassan, R. and Singh, D. (1999) Effect of applied phosphorus, sulphur and zinc on yield and uptake parameter of wheat and soybean grown on a loamy sand soil. Indian J. Agric. 69: 1-4.

(Received 30/5/2011; accepted 5/11/2012) 
أهمية إضافة الكبريت المعدنى والتلقيح الحيوى والرش بالمغذئيات

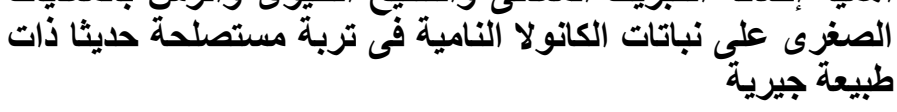

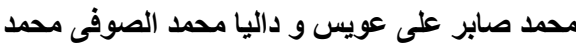

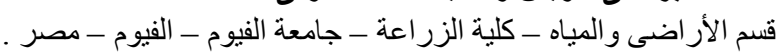

أجريت تجربة حقلية على نربة طميية طينية رملية ذات طبيعة جيرية وتعانى من

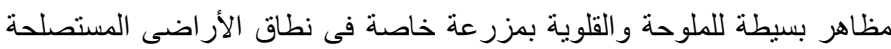

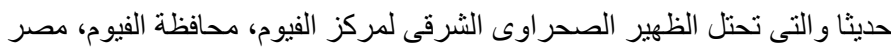

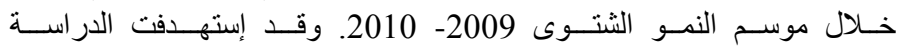

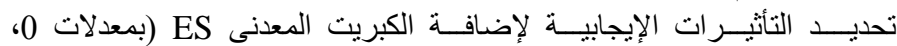

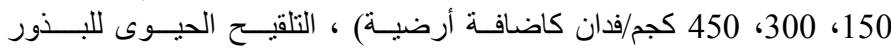
،(P-dissolving bacteria of Bacillus megatherium var. phosphaticum) PDB ورش النباتات بعناصر الحديد، المنجنيز، والزنلك، النحاس فى صورة صورة مخلبية

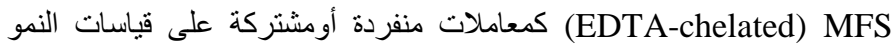

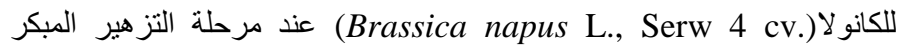

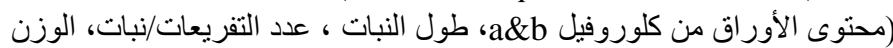

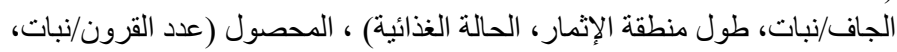

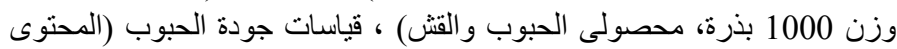

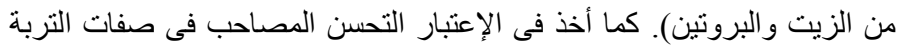

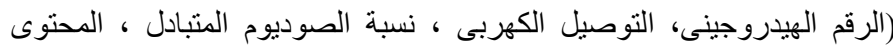

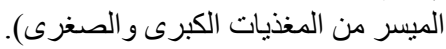

وتشير النتائج المتحصل عليها من الدراسة الحقلية أن الصفات الفيزيوكيميائية للتربة تنتمى إلى عائلة:

"Typic Torriorthents, fine loamy, mixed, hyperthermic" كما وجد أن درجة صلاحية التربة للزر اعات المروية تنتمى إلى رتبة متوسطة

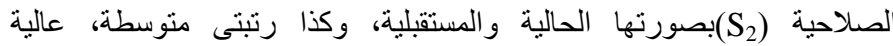

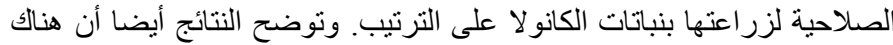

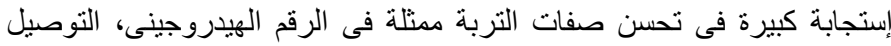

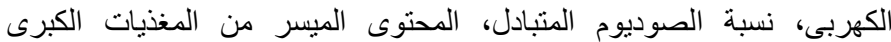

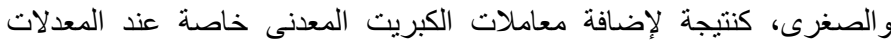

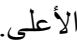

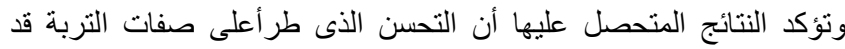

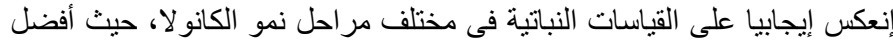

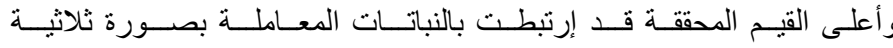

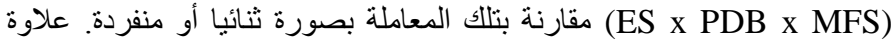

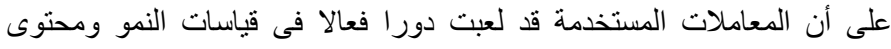

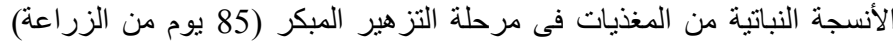




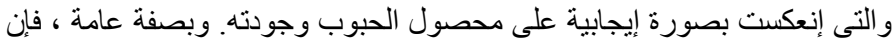

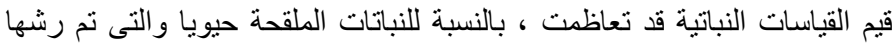

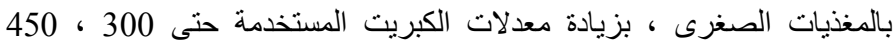

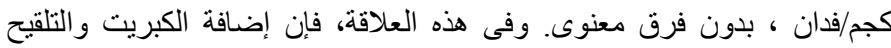

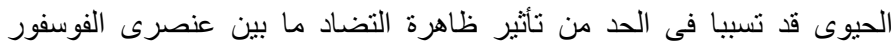
والزنك فى المحلول الأرضى، وكذا أظهرت فئ علاقة تشجيعية تمثلت فى تلأك المعاملة

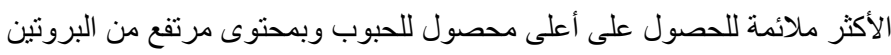
والزيت.

لــا ، يمكن التوصية بإستخدام الكبريت المعدنى والتلقيح الحيوى للبذور

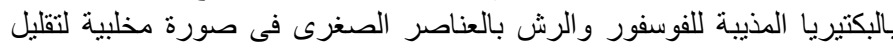

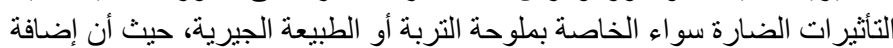

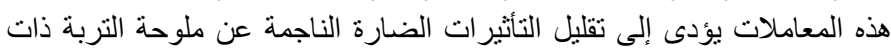

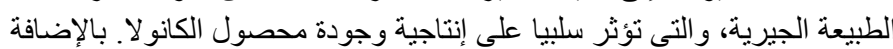

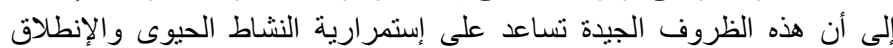

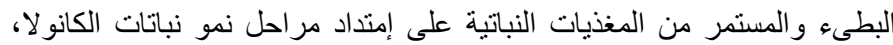

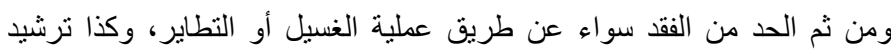

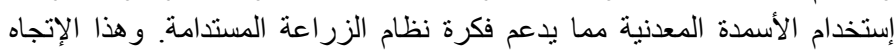

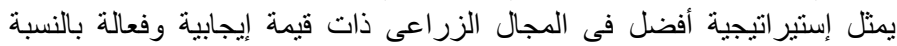
للخدمة التسميدية على المدى الطويل. 